\title{
A new genus and species of Lasiopteridi (Diptera, Cecidomyiidae) associated with Myrciaria delicatula (Myrtaceae) from Brazil, with identification keys of tribes and unplaced genera
}

\author{
Alene Ramos Rodrigues ${ }^{1,3}$, Valéria Cid Maia ${ }^{1}$, \\ Cristina Rodrigues Wenzel ${ }^{2}$ \& Milton de Souza Mendonça Junior ${ }^{2}$ \\ ${ }^{1}$ Departamento de Entomologia, Museu Nacional, Universidade Federal do Rio de Janeiro - UFRJ, \\ Quinta da Boa Vista, s/n, São Cristóvão, CEP 20940-040, Rio de Janeiro, RJ, Brazil \\ ${ }^{2}$ Departamento de Ecologia, Instituto de Biociências, Universidade Federal do Rio Grande do \\ Sul-UFRGS, Av. Bento Gonçalves, 9500, CEP 91501-970, Porto Alegre, RS, Brazil \\ ${ }^{3}$ Corresponding author: Alene Ramos Rodrigues, e-mail: alenerodrigues@yahoo.com.br
}

RODRIGUES, A.R., MAIA, V.C., WENZEL, C.R. \& MENDONÇA JUNIOR, M.S. A new genus and species of Lasiopteridi (Diptera, Cecidomyiidae) associated with Myrciaria delicatula (Myrtaceae) from Brazil, with identification keys of tribes and unplaced genera. Biota Neotrop. (13)2: http://www.biotaneotropica.org. br/v13n2/en/abstract?identification-key+bn02213022013

Abstract: Fernandesia meridionalis Rodrigues \& Maia, a new genus and species of Cecidomyiidae associated with Myrciaria delicatula O. Berg (Myrtaceae) is described and illustrated (male, female, pupa, and larva) based on material from Rio Grande do Sul, Brazil. The new genus belongs to Lasiopteridi, but it cannot be placed to tribe. A key to the tribes of Lasiopteridi and one to the unplaced genera of Neotropical Lasiopteridi are given. Keywords: Myrciaria, galler insect, taxonomy, Rio Grande do Sul.

RODRIGUES, A.R., MAIA, V.C., WENZEL, C.R. \& MENDONÇA JUNIOR, M.S. Um novo gênero e espécie de Lasiopteridi (Diptera, Cecidomyiidae) associado à Myrciaria delicatula (Myrtaceae) do Brasil, com chaves de identificação para tribos e gêneros não posicionados. Biota Neotrop. 13(2): http://www.biotaneotropica. org.br/v13n2/pt/abstract?identification-key+bn02213022013

Resumo: Fernandesia meridionalis Rodrigues \& Maia, um novo gênero e espécie de Cecidomyiidae associado à Myrciaria delicatula $\mathrm{O}$. Berg (Myrtaceae) é descrito e ilustrado (macho, fêmea, pupa e larva) baseado em material do Rio Grande do Sul, Brasil. O novo gênero pertence a Lasiopteridi, mas não pode ser posicionado em tribo. Uma chave para as tribos de Lasiopteridi e uma chave para os gêneros neotropicais não posicionados de Lasiopteridi são dadas.

Palavras-chave: Myrciaria, inseto galhador, taxonomia, Rio Grande do Sul. 


\section{Introduction}

Myrtaceae in the Neotropics are hosts of an extremely rich fauna of galling species, especially Cecidomyiidae (Diptera), as indicated in taxonomic catalogues of these insects (Gagné 1994, Maia 2005). In Brazil, it is the most attacked host plant family in restinga areas of the Southeastern region (Monteiro et al. 2004, Maia et al. 2008), and the second one in South region (Mendonça Junior 2007).

Myrciaria O.Berg is a genus of shrubs and small trees, which occurs from Mexico and the Caribbean to northern Argentina, including an estimate of up to 30 species in Brazil, mainly in the southeast (Landrum \& Kawasaki 1997). In the Rio Grande do Sul State, there are five reported species of this genus (Marchiori \& Sobral 1997). Three Cecidomyiidae species have been recorded as galls inducer on this plant genus: Dasineura myrciariae Maia 1996, Myrciariamyia bivalva Maia 1995 and Myrciariamyia fernandesi Maia 2004; the first two species are associated with leaves of Myrciaria floribunda (H. West ex Willd.) O. Berg and the other species induce bud galls on Myrciaria tenella (DC.) O. Berg (Gagné 2010, Maia 1995a, 1996, 2004).

Myrciaria delicatula O. Berg is present in the biomes: Cerrado, Mata Atlântica, Pampa; and it is geographically distributed in the following regions of Brazil: Midwest, Southeast (Minas Gerais, São Paulo, Rio de Janeiro States) and South (Paraná, Santa Catarina, Rio Grande do Sul States) (Sobral et al. 2012).

In the present work, a new genus and new species of gall midge is described - Fernandesia meridionalis gen. et spec. nov. galling Myrciaria delicatula $\mathrm{O}$. Berg.

The new genus belongs to the supertribe Lasiopteridi, characterized by two synapomorphies: the weaker aedeagus relative to that of the Cecidomyiidi and the pair of mediobasal gonocoxite lobes that laterally clasp and appear to lend support to the aedeagus (Gagné 2010).

This supertribe is divided into nine tribes, eight present in the Neotropics: Alycaulini, Camptoneuromyiini, Dasineurini, Lasiopteridi, Ledomyiini, Oligotrophini, Rhopalomyiini, and Trotterini. Among them, six are defined by apomorphies, and two (Dasineurini, and Oligotrophini) represent practical groups which are designated by convenience. They are listed and characterized below: Alycaulini (enlarged dorsal longitudinal ridges on the basal half of the ovipositor and interrupted to form rows of sclerotized and rounded bumps); Camptoneuromyiini (terminal papillae with one pair shorter than the remaining three); Dasineurini (male flagellomeres with definite necks, wing with $\mathrm{R} 5$ joining $\mathrm{C}$ at least slightly before the wing apex, a protrusible ovipositor, female eighth abdominal tergite as long or longer than seventh and tending to divide longitudinally, and male genitalia with mediobasal gonocoxite lobes that gradually taper from base to apex and are nearly as long as the aedeagus); Lasiopterini (lateral group of enlarged and flattened setae present just distal of the eighth tergite and hooked setae and a glabrous sclerotized area on the fused cerci); Ledomyiini (largely divided mediobasal gonocoxite lobes: one part is setulose, the other, usually longer and glabrous, except for apical setae); Oligotrophini (all the species associated with Cupressaceae, simple tarsal claws with very long empodia); Rhopalomyiini (sexual dimorphism with male legs and wings longer than those of the female, the female eighth tergite, when elongated, is not longitudinally divided into separate tergites, and the mediobasal gonocoxite lobes are short and blunt); and Trotteriini (elongate postocciput that covers the dorsal part of the head so that the eyes and antennae are displaced ventrad, the elongate antennal scape and pronotum, and the greatly enlarged hind femora) (Gagné 1994, 2010).
By not having any of the sets of features above, Fernandesia cannot be placed to tribe. Lasiopteridi comprise 59 genera which are also unplaced to tribe, being 21 Neotropical (Gagné 2010). An identification key of tribes Lasiopteridi and a key to segregate the Neotropical genera are provided, as well, to better characterize the new genus.

\section{Material and Methods}

Samples were taken from the National Forest of São Francisco de Paula (FLONA - SFP; 29 25' 22,4'S and 50 23' 11,2' W), in the Highlands region (900 m altitude a.s.l.) of northeastern Rio Grande do Sul state. Vegetation is mixed broadleaf-Araucaria forest (WWF ecoregion NT0101, Araucaria moist forests Da Silva 2000). Samples occurred from August 2007 to February 2009. Galls found were taken to the laboratory; half of them were open to single out immature and the other half was kept in Petri dishes with wet filter paper under room temperature, checked daily until adult emergence.

All specimens were first preserved in 96\% alcohol and later mounted on slides following the methodology of Gagné (1994). The material (including the types) was incorporated in the Diptera collection of Museu Nacional, Rio de Janeiro, Brazil. The terminology of the adult and immature stages follows Gagné (2009).

Field work and gall midge rearing were done by C. R. Wenzel and M. S. Mendonça, Jr. and the descriptions of the new taxa were done by A. R. Rodrigues and V. C. Maia.

The key of Lasiopteridi tribes was based on diagnoses of Gagné (2010). The key of unplaced genera of Neotropical Lasiopteridi were done based on original descriptions (Brethes 1917, Felt 1922, Kieffer 1913a, b, Kieffer \& Herbst 1909, 1911, Kieffer \& Jörgensen 1910 , Gagné 1994, Maia 1994, 1995b, 2001, 2007, Maia et al. 1996, 2005, Rübsaamen 1905, 1916, Tavares 1909, 1917) is presented, excepting Angeomyia Kieffer \& Herbst 1909, known only from the larva.

\section{Results and Discussion}

Fernandesia Rodrigues \& Maia, gen. nov.

Diagnosis. Adult: male circumfila irregular, made up of many short loops; palpi four-segmented; wing: $\mathrm{R}_{5}$ straight and shorter than wing, Sc and Rs absent, M3 present, $\mathrm{Cu}$ forked; tarsal claws one-toothed curved after midlength, empodia longer than bend in claws; male terminalia: cercus, hypoproct and aedeagus shorter than gonocoxites, hypoproct bilobed, mediobasal gonocoxite lobes well-developed; ovipositor barely protrusible, female cerci fused. Pupa: antennal base only slightly modified into a right angle at its anteromesal corner; prothoracic spiracle elongated; abdominal segments without dorsal spines; terminal segment bilobed. Larva: prothoracic spatula with two apical teeth; two groups of three and two lateral papillae; terminal segment bilobed, full complement of terminal papillae, with four corniform papillae on each lobe.

\section{Description:}

Adult. Head: males with $24+$ ? flagellomeres (antennae broken) and females with 28-29 flagellomeres, flagellomeres 1 and 2 connected, male circumfila wavy, male flagellomere necks striated; palpus four-segmented. Thorax: $\mathrm{R}_{1}$ reaching $\mathrm{C}$ before wing midlength, $\mathrm{R}_{5}$ straight reaching $\mathrm{C}$ before apex, $\mathrm{Sc}$ and $\mathrm{Rs}$ absent, $\mathrm{Cu}$ forked, M3 present; tarsal claws one-toothed, curved after midlength, empodia longer than bend in claws. Abdomen: male tergite 8 not sclerotized, male sternites 2-8 sclerotized, female tergites 1-8 sclerotized, female sternite 8 slightly sclerotized; male cercus ovoid, hypoproct bilobed, aedeagus shorter than gonocoxites, mediobasal 
A new genus and species of Lasiopteridi (Diptera, Cecidomyiidae) associated with Myrciaria delicatula (Myrtaceae), with identification keys

gonocoxite lobes well-developed; ovipositor barely protrusible, female cerci fused.

Pupa. Head: antennal horn reduced; full complement of frontal and facial papillae, two pairs of frontal papillae (one with seta and one bare) and three pairs of facial papillae (one with seta and others two bare). Thorax: prothoracic spiracle elongated. Abdomen: segments without dorsal spines; terminal segment bilobed.

Larva. Protoracic spatula well-developed with two triangular apical teeth, two lateral papillae groups (one group with two setose papillae and one asetose, and the other group with two setose papillae); terminal segment with two lobes, each one with four corniform terminal papillae.

Type species. Fernandesia meridionalis, Rodrigues \& Maia, spec. nov.

Etymology. The generic name is a tribute to Dr. Geraldo Wilson Fernandes, by your great contribution with the study of Cecidomyiidae in Brazil.

Remarks. This genus does not fit in any known tribe. There are 21 unplaced Neotropical genera in the supertribe Lasiopteridi. Among these, Fernandesia is compared to all other genera that have the combination of fused female cerci, short and barely protrusible ovipositor, and toothed tarsal claws (Guareamyia Tavares 1909, Guarephila Maia 2007, and Sphaeramyia Maia 2007) and it is also compared to the other Lasiopteridi genera which are associated with Myrciaria (Dasineura Rondani 1840 and Myrciariamyia Maia 1995).

Comparing with the first three genera, the new genus is unique in having antennae with 24-29 flagellomeres (15-16 in Guareamyia, 15 in Guarephila, unknown in Sphaeramyia), male circumfila wavy and palpi with four segments (male circumfila gynecoid in the three known genera, and palpi with one or two segments in the first genus and one in the remainders). Furthermore, it differs from Guareamyia and Sphaeramyia by the entirely setulose gonocoxites, reduced antennal horns and elongated prothoracic spiracles (both previously described genera have partially setulose gonocoxites, well-developed antennal horns and reduced prothoracic spiracles). Fernandesia differs from Guarephila in the length of $\mathrm{R}_{5}$ (shorter than wing in the former and as long as wing in the latter) and from Sphaeramyia in the shape of female tergite eight, prothoracic spatula and number of terminal papillae (entirely sclerotized tergite 8 , two-toothed spatula with thin stalk, and eight terminal papillae in the new genus, and not sclerotized tergite 8 , two-toothed spatula with wide stalk and two terminal papillae in Sphaeramyia). The larvae of Guareamyia and Guarephila as well as the pupa of Guarephila were not compared with those of the new genus because they are still unknown.

Considering the Lasiopteridi genera which are associated with Myrciaria (Dasineura, Myrciariamyia and Fernandesia), the new genus is the unique whose larva presents with five pairs of lateral papillae (both genera with six pairs). Fernandesia differs to Dasineura by having short and barely protrusible ovipositor (elongated and protrusible in the other). And it differs from Myrciariamyia in having fused female cerci, R5 shorter than wing, larva with clove-shaped spatula and eight terminal papillae (cerci separated, R5 as long as wing, spatula reduced and six terminal papillae in the other genus).

Fernandesia meridionalis, Rodrigues \& Maia, spec. nov.

Adult. Body length: 3.46-3.64 mm in male $(\mathrm{n}=2) ; 4.31-5.16 \mathrm{~mm}$ in female $(\mathrm{n}=6)$.

Head (Figure 1). Eye facets circular closely approximated, except at the vertex, without facets. Antenna with scape obconic; pedicel globose; 28-29 flagellomeres in female, (male antennae broken beyond $24^{\text {th }}$ flagellomere); distal flagellomeres gradually shortened than basal; male flagellomeres with irregular circumfila, made up of many short loops (Figure 2); female flagellomeres with circumfila as two connected rings (Figure 3), with variations as in figures 4 to 8 ; flagellomere necks short in both sexes, longer and striated in males; flagellomeres 1 and 2 connected. Hypopharynx and labella with a variable number of setae medially, 5-8 and 7-12, respectively. Palpi four-segmented, length of segments gradually increasing from first to last.

Thorax. Wing (Figure 9): length: 2.12-2.35 $\mathrm{mm}$ in male $(\mathrm{n}=4)$; 2.70-3.00 mm in female $(n=5) ; R_{1}$ reaching $C$ before wing midlength, $\mathrm{R}_{5}$ straight reaching $\mathrm{C}$ before apex, $\mathrm{Sc}$ and $\mathrm{Rs}$ absent, $\mathrm{Cu}$ forked, $\mathrm{M}_{3}$ present. Tarsal claws toothed, curved after midlength, empodia longer than bend in claws (Figure 10).

Abdomen. Male (Figure 11): tergites 1- 6 ovoid, with complete row of caudal setae, two basal trichoid sensilla; tergite 7 rectangular weakly sclerotized caudally, with complete row of caudal setae, two basal trichoid sensilla; tergite 8 not sclerotized, with only two basal trichoid sensilla; sternites 2-8 rectangular, with setae more abundant medially, a complete row of caudal setae, two basal trichoid sensilla. Female (Figure 12): tergites 1-8 rectangular, with complete row of caudal setae, two basal trichoid sensilla; sternites 2-7 rectangular, with setae more abundant medially, a complete row of caudal setae, two basal trichoid sensilla; sternite 8 slightly sclerotized. Male terminalia (Figure 13 and 14): gonocoxites ovoid, mediobasal gonocoxite lobes wide and setose, gonostylus slender, tapering gradually to apex; cercus ovoid and setose; hypoproct bilobed slightly longer than cercus; aedeagus longer than hypoproct, rounded at apex. Ovipositor barely protrusible (Figure 12) with several ventral setae, cerci ovoid setose (Figure 15).

Pupa. Body length: 3.92-5.30 mm $(\mathrm{n}=2)$. Cephalic region (Figure 16): antennal horn reduced; apical setae with 0.15-0.25 mm in length $(\mathrm{n}=2)$; two pairs frontal papillae, one with seta and other bare; three pairs facial papillae, one with seta and other two bare; upper cephalic margin thickened laterally. Thorax: prothoracic spiracle (Figure 16) elongated, slightly curved and sclerotized in the apex, with $0.32-0.39 \mathrm{~mm}$ in length $(\mathrm{n}=2)$. Abdomen: without dorsal spines; terminal segment bilobed (Figure 17).

Larva. Body length: 4.37-4.55 mm $(\mathrm{n}=2)$. Body elongated and cylindrical tapering to ends (Figure 18); prothoracic spatula with $0.19-0.25 \mathrm{~mm}$ in length $(\mathrm{n}=2)$, with two well-developed apical teeth (Figure 19); two groups of lateral papillae, one with two setose papillae and the other with three papillae (two setose and one bare) (Figure 20); terminal segment with two lobes, each with four corniform papillae (Figure 20).

Gall (Figure 21). Consists of two main opposite leaves held together by their margins (like a bivalve) but with a bulging shape, nearly spherical. It is $10 \mathrm{~mm}$ long overall, and on its base a few small, stunted light green opposite leaves are present. Main leaves are thin and of a rosy color similar to that of young leaves. They are nearly translucid and the larva can be seen against a light source. A single chamber is found, inside which no apparent nutritive tissue develops.

Occurrence. This gall is very rare in FLONA Conservation Unit. It occurred on only one out of 6 trails sampled, in preserved forest, and although sampling covered more than a year, it was found only in October 2007.

Type material. Holotype $\widehat{\delta}$. BRAZIL, Rio Grande do Sul: São Francisco de Paula, xi.2007, M. Mendonça col. MNRJ. Paratypes: same data as holotype, $3 \AA, 6$, 2 pupal exuvia and 2 larvae.

Etymology. The specific name is the genitive of the collection place of the material, in the southern region of the country. 

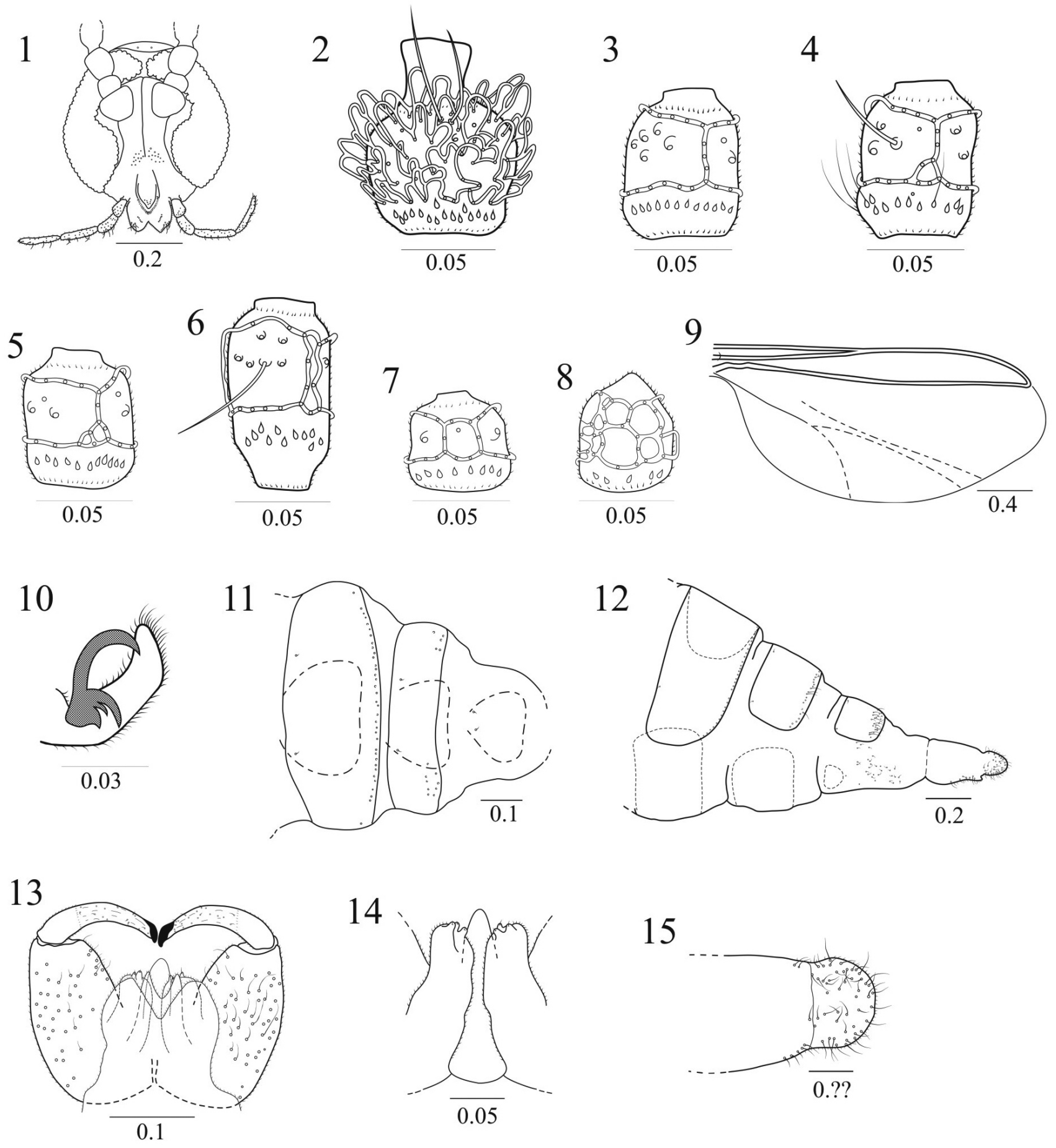

Figures 1-12. Fernandesia meridionalis spec. nov. Rodrigues \& Maia, - 1: Male head, frontal view; - 2: male flagellomere 5; - 3-8: female flagellomeres, 3: flagellomere 7; 4: flagellomere 5, 5: flagellomere 9, 6: flagellomere 2, 7: flagellomere 22, 8: flagellomere 28; - 9: male wing; - 10: male tarsal claw and empodium, lateral view; - 11: male abdominal segments 6-8, dorsal view; - 12: female abdominal segments 6-8 and ovipositor, dorsal-lateral view. Scale bars in millimeters.

\section{Key to tribes of Neotropical Lasiopteridi}

1. Male seventh tergite setose along caudal margin and sclerotized at least posteriorly; basal half of ovipositor with dorsal striae interrupted and enlarged to form series of sclerotized, pigmented bumps Alycaulini

- Male seventh tergite unsclerotized posteriorly, setae and scales lacking or present only laterally; ovipositor on basal half without series of sclerotized, pigmented bumps
2. Larva with four pairs of terminal papillae, one pair shorter than the remaining three; R5 short (one- third to one-half the length of the wing); short antennae in both sexes Camptoneuromyiini

- Larva with a distinct complement of terminal papillae, R5 variable; antennae not short.....

... 3

3. Male flagellomeres with definite necks; R5 joining C slightly before wing apex; protrusible ovipositor; female eigthth tergite longer than the seventh and tending to divide longitudinally; male gonocoxite 

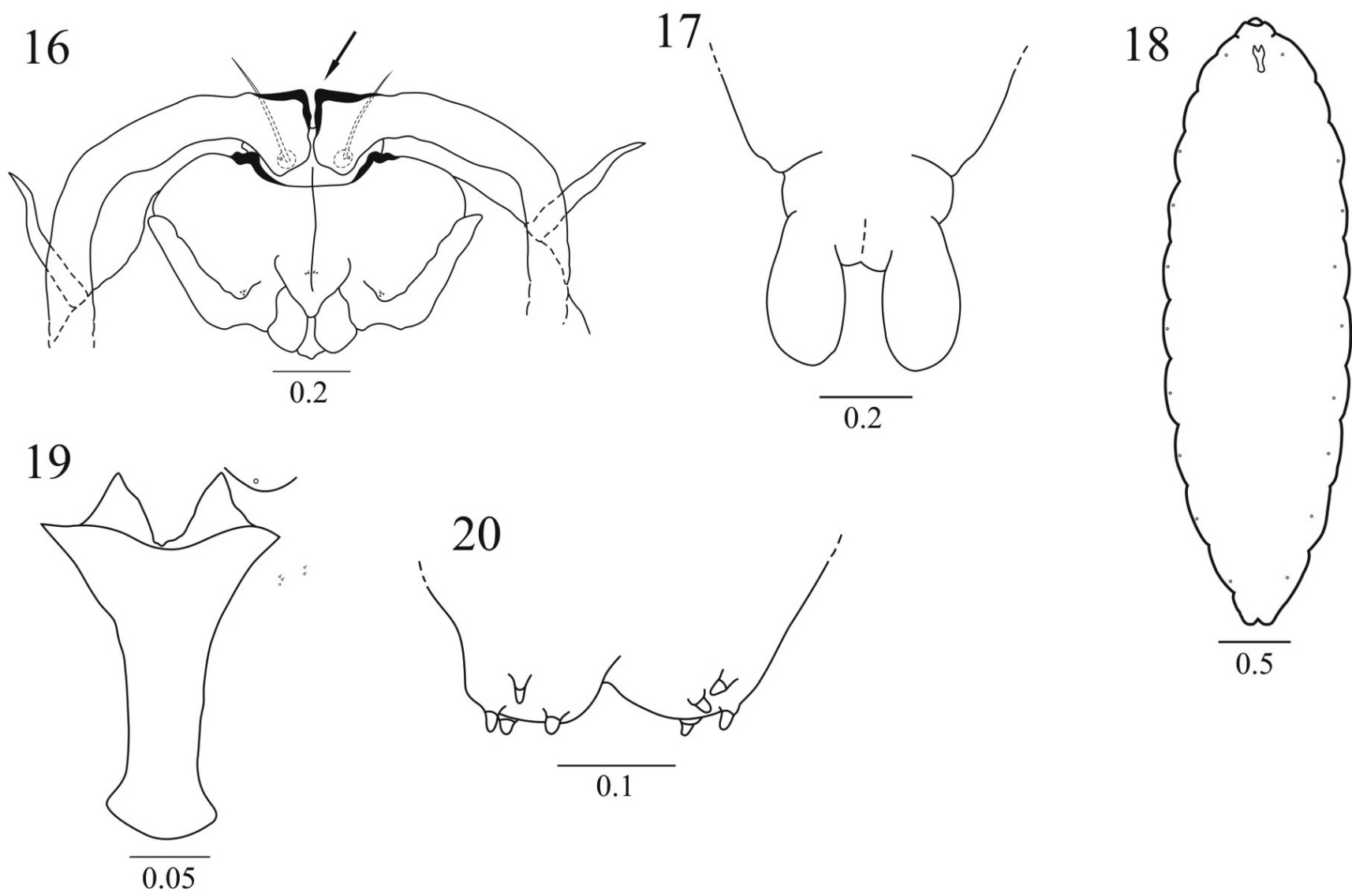

Figures 13-20. Fernandesia meridionalis spec. nov. Rodrigues \& Maia, -13: Male terminalia, dorsal view; - 14: detail male terminalia, aedeagus and parameres, ventral view; - 15: detail ovipositor, cerci, dorsal view. - 16: pupa, cephalic region, frontal view, arrow indicating antennal base; - 17: pupa, terminal segments, dorsal view; - 18: larva, general aspect, ventral view; - 19: larva, prothoracic spatula and lateral and sternal papillae, ventral view; - 20: larva, terminal segment and papillae, ventral view. Scale bars in millimeters.

\section{1}

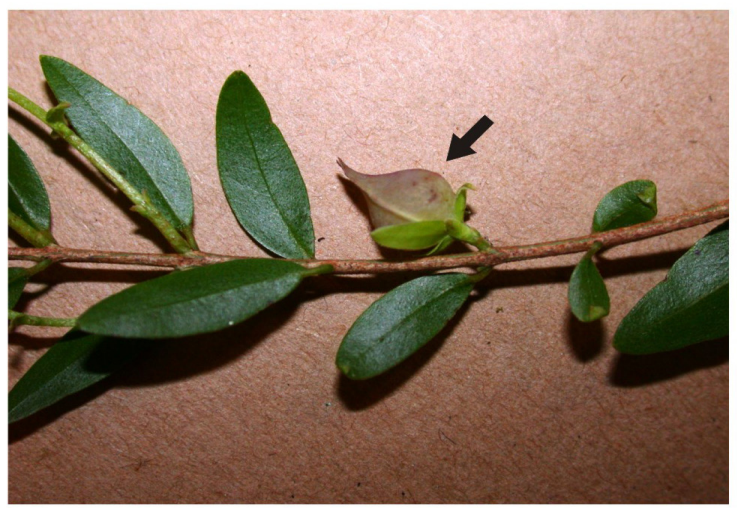

Figure 21. Gall in leaves in Myrciaria delicatula O.Berg (Myrtaceae).

lobes gradually tapering from base to apex and nearly as long as aedeagus .

Dasineurini

- Not like that 4

4. Basal half of ovipositor with lateral group of numerous, strong, modified setae; fused cerci with hooked setae

Lasiopterini (one Neotropical genus: Incolasioptera)
- Basal half of ovipositor without such setae; cerci without hooked setae

5. Gonocoxite lobes divided into two parts, one setulose and other usually longer, glabrous except for apical setae; female cerci separate ..Ledomyiini (one Neotropical genus: Ledomyia)

- Gonocoxite lobes entire, cerci variable

6. Tarsal claws simple with very long empodia, from Cupressaceae

....... Oligotrophini

-Tarsal claws variable, from other hosts 7

7. Legs and wings with sexual dimorphism (longer in males); gonocoxite lobes short and blunt

Rhopalomyiini (one genus: Rhopalomyia)

- Legs and wing without sexual dimorphism; gonocoxite lobes not short and blunt

8. Elongate postocciput covering the dorsal part of the head; eyes and antennae displaced ventral; elongate scape and pronotum; hind femora greatly enlarged Trotterini (one genus: Trotteria)

- Postocciput, eyes, antennae, scape, pronotum and hind femora normal unplaced genera

\section{Key to unplaced genera of Neotropical Lasiopteridi} larva)

(Angeiomyia was not included because it is known only from

1. Ovipositor not or barely protrusible; female cerci fused; tarsal claws toothed 
- Ovipositor elongate-protrusible; female cerci separate; tarsal claws simple.

2. Female tergite eight not sclerotized ..... Sphaeramyia Maia 2007

- Female tergite eight sclerotized

3. Antenna with 15 flagellomeres; R5 as long as wing.

Guarephila Tavares 1909

- Antenna with 15 or more flagellomeres; R5 shorter than wing .. 4

4. Antenna with 15-16 flagellomeres; male circumfila as two connected rings, palpus with one or two segments; gonocoxites partially bare ..... Guareamyia Maia 2007

- Antenna with 24-29 flagellomeres; male circumfila wavy, palpus with four segments; gonocoxites completely setulose

Fernandesia gen. nov.

5. Palpus with one segment; tarsal claws toothed .......................... 6

- Palpus with two or more segments; tarsal claws simple ............ 10

6. Ovipositor elongate-protrusible .............................................. 7

- Ovipositor not or barely protrusible ............................................ 8

7. R5 shorter than wing .................. Novocalmonia (Tavares 1917)

- R5 as long as wing ................... Scheueria Kieffer \& Herbst 1909

8. Antenna with 24 flagellomeres; antennal horns elongated with serrated margins ................................. Haplopalpus Rübsaamen 1916

- Antenna with 14-20 flagellomeres; antennal horns elongated or reduced with not serrated margin .....

9. Antenna with 14-18 flagellomeres; R5 as long as wing; gonocoxites completely setulose ............... Jorgenseniella Maia 2005

- Antenna with 19-20 flagellomeres; R5 longer than wing; gonocoxites partially bare Mayteniella Maia 2001

10. Palpus with two segments Uleia Rübsaamen 1905

- Palpus with three or more segments ........................................ 11

11. Palpus three-segmented .................................................... 12

- Palpus four-segmented .............................................................. 16

12. Tarsal claws simple ............................................................ 13

- Tarsal claws toothed ................................................................ 14

13. Antenna with 15 flagellomeres; R5 longer than wing ................ ..Lyciomyia Kieffer \& Jörgensen 1910

- Antenna with 17 flagellomeres; R5 as long as wing Pseudomikiola Brèthes 1917

14. R5 longer than wing; gonocoxites completely setulose . Ficiomyia Felt 1922

- R5 as long as wing; gonocoxites partially bare

15. Female tergite eight entire ............ Neomitranthella Maia 1996

- Female tergite eight not sclerotized ..... Paulliniamyia Maia 2001

16. R5 shorter than wing ................. Eugeniamyia Maia et al. 1997

- R5 as long as wing.....

17. Antenna with 20-29 flagellomeres; pupa antennal horns reduced ... 18

- Antenna with 15-19 flagellomeres; pupa antennal horns welldeveloped

18. Antenna with 23-29 flagellomeres; ovipositor not or barely protrusible; female cerci separate; pupa abdominal segments without dorsal spines Myrciariamyia Maia 1995

- Antenna with 20 flagellomeres; ovipositor elongate-protrusible; female cerci fused; pupa abdominal segments with dorsal spines ........ . Pernettyella Kieffer \& Herbst 1909

19. Antenna with 19 flagellomeres; pupa prothoracic spiracle reduced Xyloperrisia Kieffer 1913

- Antenna with 15-17 flagellomeres; pupa prothoracic spiracle elongated

20. Antenna with 17 flagellomeres; ovipositor not or barely protrusible; female cerci separate; pupa prothoracic spiracle strongly sclerotized
- Antenna with 15 flagellomeres; ovipositor elongate-protrusible; female cerci fused; pupa prothoracic spiracle slightly sclerotized ........ Riveraella Kieffer \& Herbst 1911

\section{Acknowledgments}

MMJ and CRW would like to thank C.A. Iserhard for help in the field, Guilherme Ceolin for plant identification, the people of FLONA-SFP for logistic support, and also CNPq (Conselho Nacional de Desenvolvimento Científico e Tecnológico) for financial support (Proc. 472084/2007-0 and 157622/2010-0).

\section{References}

BRETHES, J. 1917. Description d'une cécidie et de sa cécidomyie d'une Lippia d'Entre Rios. Physis (3):411-413.

DA SILVA, J.M.C. 2000. Araucaria moist forests (NT0101). http://www. worldwildlife.org/wildworld/profiles/terrestrial/nt/nt0101_full.html (último acesso em 18/05/2010).

FELT, E.P. 1922. A new and remarkable fig midge. Florida Entomol. 6:5-6. http://dx.doi.org/10.2307/3492798

GAGNÉ, R.J. 1994. The gall midges of the Neotropical region. Cornell University Press, Ithaca, 352p.

GAGNÉ, R.J. 2009. Cecidomyiidae (gall midges). In Manual of Central American Diptera: Volume 1 (B.V. Brown, A. Borkent, J.M. Cumming, D.M. Wood, N.E. Woodley \& M. Zumbado). NRC Research Press, Ottawa, $714 \mathrm{p}$.

GAGNÉ, R.J. 2010. Update for a catalog of the Cecidomyiidae (Diptera) of the world. Digital version 1. http://www.ars.usda.gov/SP2UserFiles/ Place/12754100/Gagne_2010_World_Catalog_Cecidomyiidae.pdf (último acesso em 20/02/2013).

KIEFFER, J.J. 1913a. Glanures diptèrologiques. Bull. Soc. d'Histoire Nat. Metz, 28:45-55.

KIEFFER, J.J. 1913b. Diptera Fam. Cecidomyiidae. Genera Insectorum, V.152, p.1-346.

KIEFFER, J.J. \& HERBST, P. 1909. Uber einige neue Gallen und Gallenerzeuger aus Chile. Central. Bakteriol. Parasitenk. Infektionskran. 23(2):119-126.

KIEFFER, J.J. \& HERBST, P. 1911. Uber Gallen und Gallenerzeuger aus Chile. Central. Bakteriol. Parasitenk. Infektionskran. 29(2):696-704.

KIEFFER, J.J. \& KÖRGENSEN, P. 1910. Uber Gallen und Gallenerzeuger aus Argentinien. Central. Bakteriol. Parasitenk. Infektionskran. 27(2):362444.

LANDRUM, L.R. \& KAWASAKI, M.L. 1997. The genera of Myrtaceae in Brazil: an illustrated synoptic treatment and identification keys. Brittonia 49(4):508-536. http://dx.doi.org/10.2307/2807742

MAIA, V.C. 1994. Myrciariamyia bivalva, gen. n. e sp. n. (Diptera, Cecidomyiidae, Oligotrophini) associado com Myrciaria floribunda (Camb.) Legr. (Myrtaceae) no Brasil. Rev. Bras. Zool. 11(4):635-639. http://dx.doi.org/10.1590/S0101-81751994000400007

MAIA, V.C. 1995a. Myrciariamyia bivalva, gen. n. e sp. n. (Diptera, Cecidomyiidae, Oligotrophini), associado com Myrciaria floribunda (Camb.) Legr. (Myrtaceae) no Brasil. Rev. Bras. Zool. 11(4):635-638. http://dx.doi.org/10.1590/S0101-81751994000400007

MAIA, V.C. 1995b. Dois gêneros novos de Cecidomyiidae (Diptera) associados à Myrtaceae, na Restinga da Barra de Maricá, Rio de Janeiro, Brasil. Rev. Bras. Zool. 12(3):567-574. http://dx.doi.org/10.1590/S010181751995000300012

MAIA, V.C. 1996. Três espécias novas de Dasineura Rondani (Diptera, Cecidomyiidae) associadas a Myrtaceae, na restinga de Barra de Maricá, Rio de Janeiro. Rev. Bras. Zool. 12:1001-1008. http://dx.doi.org/10.1590/ S0101-81751995000400027

MAIA, V.C. 2001. The gall midges (Diptera, Cecidomyiidae) from three restingas of Rio de Janeiro State, Brazil. Rev. Bras. Zool. 18(2):305-656. http://dx.doi.org/10.1590/S0101-81752001000200028 
MAIA, V.C. 2004. A new genus and six new species of gall midges (Diptera, Cecidomyiidae) from serra de São José (Minas Gerais State), Brazil). Arq. Mus. Nac. (62):69-82.

MAIA, V.C. 2005. Catálogo dos Cecidomyiidae (Diptera) do Estado do Rio de Janeiro. Biota Neotrop. 5(2): http://www.biotaneotropica.org.br/v5n2/ pt/abstract?inventory+BN00805022005 (último acesso em 03/09/2010).

MAIA, V.C. 2007. New genera and species of gall midges (Diptera, Cecidomyiidae) associated with Guarea macrophylla (Myrtaceae). Rev. Bras. Zool. 24(2):449-456. http://dx.doi.org/10.1590/S010181752007000200024

MAIA, V.C., CONSTANTINO, P.A.L. \& MONTEIRO, R.F. 2005. New gall midges (Diptera, Cecidomyiidae) associated with two species of Eugenia (Myrtaceae). Rev. Bras. Entomol. 49(3):347-352. http://dx.doi. org/10.1590/S0085-56262005000300004

MAIA, V.C., MAGENTA, M.A.G. \& MARTINS, S.E. 2008. Ocorrência e caracterização de galhas de insetos em áreas de restinga de Bertioga (São Paulo, Brasil). Biota Neotrop. 8: http://www.biotaneotropica.org.br/v8n1/ pt/abstract?inventory+bn02408012008.

MAIA, V.C., MENDONÇA JUNIOR, M. \& ROMANOWSKI, H.P. 1996. Eugeniamyia Dispar gen. n. and sp.n. (Diptera, Cecidomyiidae, Lasiopteridi) associated with Eugenia uniflora L. (Myrtaceae) in Brazil. Rev. Bras. Zool. 13(4):1087-1090. http://dx.doi.org/10.1590/S010181751996000400026
MARCHIORI, J.N.C. \& SOBRAL, M. 1997. Dendrologia das Angiospermas. Myrtales, Editora UFSM, Santa Maria.

MENDONCA JUNIOR, M.S. 2007. Plant diversity and galling arthropod diversity searching for taxonomic patterns in an animal-plant interaction in the Neotropics. Bol. Soc. Argent. Bot. 42(3-4):347-357.

MONTEIRO, R.F., ODA, R.A.M., NARAHARA, K.L. \& CONSTANTINO, P.A.L. 2004. Galhas: diversidade, especificidade e distribuição. In Pesquisas de Longa Duração na Restinga de Jurubatiba. Ecologia, História Natural e Conservação (C.F.D. Rocha, F.A. Esteves \& F.R. Scarano, eds.). RiMa Editora, São Carlos, p.127-142.

RÜBSAAMEN, E.H. 1905. Beiträge zur Kenntnis aussereuropäischer Zoocecidien. II. Betrag: Gallen aus Brasilien und Peru. (Vorläufige Mitteiling) Marcellia 4:65-85.

RÜBSAAMEN, E.H. 1916. Beiträge zur Kenntnis aussereuropäischer Gallmücken. Sitz.ber. Ges. Nat.forsch. Freunde Berl. 1915: 431-481.

SOBRAL, M., PROENÇA, C., SOUZA, M., MAZINE, F. \& LUCAS, E. 2012. Myrtaceae in Lista de Espécies da Flora do Brasil. Jardim Botânico do Rio de Janeiro. http://floradobrasil.jbrj.gov.br/2012/FB010789 (último acesso em 20/02/2013).

TAVARES, J.S. 1909. Contributio prima ad cognitionem cecidologiae braziliae. Brotéria, Sér. Zool. 8:5-28, pls. I-VIII.

TAVARES, J.S. 1917. Cecídias brasileiras que se criam em plantas das famílias das Compositae, Rubiaceae, Tiliaceae, Lythraceae e Artocarpaceae. Brotéria, Sér. Zool. 15:113-181, pls. VI-XI. 